\title{
Urban natural environments in teaching younger school children
}

\author{
Tatyana Kropocheva ${ }^{1^{*}}$ and Mariya Sineva ${ }^{1}$ \\ ${ }^{1}$ Novokuznetsk Institute (Branch) of Kemerovo State University, Faculty of Psychology and \\ Pedagogy, Novokuznetsk, Russia
}

\begin{abstract}
Under the conditions of intensive introduction of information technologies into learning practice (presentations, e-books) and various printed media (printed notebooks, dictionaries and reference books), teachers everywhere have ceased to perform nature tours, and during lessons devoted to Surrounding World it becomes common to study nature without nature. Observations of nature and laboratory experiments, introduced in the 19th century to methods of teaching natural science, were referred to as the main methods of teaching natural science to younger schoolchildren in the 20 th century. However, in the 21 st century the observations nearly disappeared from elementary school, and experiments are performed either as home assignments or are substituted with presentations. Aiming at elimination of drawbacks of verbal presentation of Surrounding World discipline, becoming more and more popular in modern elementary school, the authors tried to analyze the opportunities of close natural surrounding for organization of research activity by younger pupils. This article discusses educational opportunities of the use of urban natural environment in formation of direct observations and nature study by younger pupils. Information about the natural and climatic features of the urban environment, about diversity of flora and fauna species can be useful for the teacher. The mentioned features are exemplified by natural environment of city schools in Kemerovo oblast. Floristic lists of trees and shrubs at schoolyards of some schools in Kuzbass are provided as well as specifications of species diversity of various classes of animal world of the mentioned cities (birds, mammals, amphibians, reptiles, and insects). And though the urban natural environment cannot be considered as rich, the species diversity of synanthropes and ruderal plants of urban nature present wide opportunities as learning material to train investigative researchers capable to see, to analyze, to compare, and to generalize natural phenomena. Keywords: research and teaching activity, urban natural environment, sphere of urban impact on nature.
\end{abstract}

\section{Introduction}

The educational standard for the discipline Surrounding World concerning younger pupils stipulates formation of notions and skills to observe nature, to carry out simple measurements

* Corresponding author: kropocheva87@yandex.ru 
and experiments with natural objects, to work with models and geographic maps, to orient with respect to the terrain [1]. The mentioned skills promote development of capacities of younger pupils to research the closest natural surroundings. Since most Russian pupils are urban citizens, then the closest natural surroundings are urban nature.

Analysis of program documents of modern elementary schools demonstrates that a younger pupil upon studying surrounding world becomes familiarized not only with nature but also with social environment. Modern textbooks of surrounding world are based on encyclopedic principle, that is, formation of elemental orientation of pupil in natural geographic and societal fields. However, the methodological substantiation of practical skills of younger pupils in new content of natural education lags behind both in theory, and in practice of teaching.

\section{Methods}

Investigating activity of pupils is one of the advanced forms of education in comprehensive school of the 21 st century, since it allows to fully reveal and to develop both intellectual and creative capacities of children. In addition, systematic and activity driven approach to education [1] can be developed only on the basis of organization of motivated targeted activities of pupils, one of them is investigations.

Educational and research activity (educational research) is the form of organization of educational process related with solution to creative task by pupils, where due to the novelty (uncertainty) of result a pupil should perform educational discovery [2-5].

Teachers developed a system of educational methods promoting development of research activity of younger pupils upon studying Surrounding World discipline, namely: role play, observation, description and definition of studied objects, experiments, discussion, structuring educational material (text), designing, modelling, etc. [6-10].

Nature studies by younger pupils can be organized only in the nearest natural environment, since long-range travelling in younger classes is not recommended. Therefore, the authors faced the necessity to analyze educational opportunities of using urban natural environment of Kemerovo oblast aiming at organization of research activities of pupils.

\section{Results and discussion}

Some teachers believe that in the case of urban schools, the nature is so depleted that it is impossible to perform any investigations. Unfortunately, such erroneous opinion leads to nonfulfillment of requirements of educational standard [1] and major educational program [11-13] on implementation of practical orientation of Surrounding World course in most urban schools, and as a consequence, to formalism of pupils' knowledge. As a result of such education, younger pupils do not obtain skills to observe nature, stipulated by the program, knowledge about species diversity of local flora and fauna, and the wish to protect nature is not implemented in practice.

Meanwhile, the issue of use of urban natural environment during studying nature science emerged from the time of establishment of public schools in cities in the 18th century. Thus, on the background of commonly recognized verbal teaching, in 1786 academician V.F. Zuev proposed for the first time to use local natural material upon teaching of natural history. In the 19th century A.Ya. Gerd declared obligatory studies of natural object by pupils in connection with its habitat. Early in the 20th century D. N. Kaigorodov and V. V. Polovtsov popularized introduction of sightseeing and biological education methods into school, due to which the studies of nature were not a dogma but were based on personal perceptions and independent research of pupils. While understanding that teachers might not be well 
acquainted with local flora and fauna, scientists developed special recommendations on organization of seasonal travelling in suburbs of St. Petersburg, during which, exemplified by the same routes in the suburb park, it was possible to trace seasonal variations of animate and inanimate urban nature.

Later on, K.P. Yagodovskii described the method of excursion in the context of studying the native nature and mentioned that it was impossible to learn children to understand the laws of surrounding nature without its direct studies. N.M. Verzilin proposed various specifications of excursions and subject lessons: observations of plants and animals of schoolyard, determination of degree of their damage and recovery, phenological reports of observations, planting.

In modern elementary school, despite rich history of development of the use of natural environment for studying pupils in Surrounding World course, solution to this issue cannot be considered as positive. In younger classes, the teachers have become so attracted to working with didactic aids that a lesson of surrounding world has transformed into rustling the pages of textbooks and workbooks.

In relation with the considered problem, in the context of analysis of conditions of successful observation of nature in a city, the authors faced the task to study natural environment of urban schools in Kemerovo oblast. Starting from the 1930-s, in Kuzbass heavy industry was developing rapidly, cities grew, leading to sharp variation of the environment for humans and other living organisms, and not for the better.

Urban environment conditions are a set of abiotic and biotic factors, processes, and phenomena, varied or newly created by business activity of humans in the territory determined by urban boundary. The urban impacts on nature are summarized in Table 1:

Table 1. Sphere of urban impact on nature.

\begin{tabular}{|c|c|}
\hline Climate & Relief \\
\hline $\begin{array}{c}\text { - increase in air temperature, } \\
\text { - decrease in solar radiation, } \\
\text { - increase in cloudiness, } \\
\text { - increase in number of foggy days, } \\
\text { - increase in precipitation, } \\
\text { - increase in humidity }\end{array}$ & $\begin{array}{l}\text { - emergence of artificial relief forms (quarries, } \\
\text { waste dumps), } \\
\text { - lowering or elevation of reference marks, } \\
\text { - disappearance of natural microrelief, } \\
\text { - erasing of geomorphological boundaries }\end{array}$ \\
\hline Atmosphere & Soils \\
\hline $\begin{array}{l}\text { - mechanical pollution, } \\
\text { - chemical pollution, } \\
\text { - smog formation, } \\
\text { - increase in carbon dioxide content }\end{array}$ & $\begin{array}{l}\text { - cessation of soil formation, } \\
\text { - formation of artificial soils, } \\
\text { - pollution and compaction of soils, } \\
\text { - cultivation of primary soils }\end{array}$ \\
\hline Animal world & $\begin{array}{l}\text { Plant world } \\
\end{array}$ \\
\hline $\begin{array}{c}\text { - destruction of natural fauna, } \\
\text { - creation of conditions for synanthropes, } \\
\text { - creation of artificial conditions for } \\
\text { attraction of wild species }\end{array}$ & $\begin{array}{l}\text { - destruction of natural flora, } \\
\text { - artificial planting, } \\
\text { - introduction of azonal flora }\end{array}$ \\
\hline
\end{tabular}

The features of climate and relief mentioned in Table 1 exert significant impact on flora and fauna of urban environment. It should be mentioned that in cities, due to warmer climate, the snow melts earlier, plants blossom, atypical heat-loving plants can grow in the area. Thus, in the cities of Kemerovo oblast, broad-leaved trees are used, not characteristic for wild nature: ash-leaved maple and Tatarian maple, elm, white and Lombardy poplar, English oak, nine-bark, silverberry, blue spruce, etc. [14].

Since high temperature can occur in the cities due to asphalt (up to $40-45^{\circ} \mathrm{C}$ ), then the mentioned heat-loving plants can die due to the heat. Soil and air pollutions with harmful substances impact negatively the plants.

In order to estimate the state of school plantings in Kemerovo oblast, the floristic lists of 
trees and shrubs at schoolyards were made in the following cities: Novokuznetsk, Osinniki, Prokopyevsk. Analysis of species composition of trees and shrubs demonstrated that in total about 398 species were used for greening of schoolyards in Kemerovo oblast. In the schoolyards of $7 \%$ of schools, 20 and more plant species were planted; $59 \%$ of schools had 15-18 plant species; $34 \%$ of schools had schoolyards with 10 or less trees and shrubs species.

The dominating species were common birch, Chinese elm, common lilac, ash-leaved maple, balsam poplar, Siberian rowan, nine-bark, i.e., trees and shrubs common for Western Siberia.

It should be mentioned that upon conversations with teachers of elementary schools of Kemerovo oblast, more than half of them considered the urban nature sufficiently depleted for excursions. However, such opinion about depleted state of school natural environment is improper. In this regard, the words of V.F. Natali should be recalled, who wrote: "I state that there is not a single school in any city, where it is impossible to perform excursions giving rich material for observations" [15].

The animal world of the cities of Kemerovo oblast has not been studied in details; however, according to zoological reference books, the cities are populated with animals of all classes: mammals (dogs, cats, mice, rats, dibblers, moles, ground squirrels, muskrats), reptiles (lizards and snakes), amphibians (frogs and toads), fish in urban rivers (perch, gudgeon, pike), numerous insects (ants, flies, wasps, carabus, ladybirds, grasshoppers, cicadas). As for the urban birds, they are so diverse that it is possible to observed them all the year round: in winter and autumn, sedentary birds (crow, magpie, nutcracker, sparrow, pigeon, tomtit, goldfinch) and migrating birds (bullfinch and waxbird) are seen; in spring, other migrating birds appear (swift, flycatcher, redstart, starling, rosefinch, lapwing, wild duck, sandpiper).

The features of urban animals should be mentioned, which obviously vary due to peculiar conditions of climate, soils, and urban plants. Most animals search for feed at garbage heaps, that is, they are transformed from wild to synanthropes. The synanthrope properties are peculiar not only to crows and pigeons, but also to tomtits, sparrows, magpies. The cases of begging by many birds are observed. Some migrating birds (ducks, starlings) ceased their traveling to south in winters, since feed (garbage heap) and warm dwelling (attics) can be found in cities all the year round [14].

\section{Conclusion}

The presented description of urban natural environment of Kemerovo oblast allows to state that the urban nature is one of the best tools for teaching younger pupils about the surrounding world. Closeness to school, accessibility for observation and study, sufficient species diversity of plants and animals, great cultural and recreational value determine the opportunity to use the urban environment in various forms of educational process at elementary school. Nevertheless, this requires for special organization methods of studying urban nature by pupils.

One of the main methods of urban nature researching is observation. This method is available for teacher and pupils in organization and performance, as well as promotes strongly development of researching skills of pupils.

\section{References}

1. Ministry of Education and Science of the Russian Federation, Federal'nyy gosudarstvennyy obrazovatel'nyy standart nachal'nogo obshchego obrazovaniya 
[Federal State Educational Standard Of Primary General Education] (Prosveshcheniye, Moscow, 2010)

2. L.G. Balakshina, N.M. Kirichenko, Issledovatelskaya deyatelnost mladshikh shkolnikov [Research activity of younger students], Otkrytyi urok "Pervoye sentyabrya" (2008). Accessed on: September 25, 2020. [Online]. Available: https://urok.1sept.ru/articles/509737

3. O.S. Bekish, Nachalnaya shkola, 3, 40-45 (2020)

4. A.I. Savenkov, Fizika: prabliemy vykladannia, 3, 14-24 (2007)

5. A.I. Savenkov, Metodika issledovatelskogo obucheniya mladshikh shkolnikov [Research teaching methodology for primary schoolchildren] (Dom Fedorova, Moscow, 2015)

6. O.V. Alekseeva, A.A. Araslanova, Okruzhayushchiy mir. Osobennosti izucheniya predmeta $\mathrm{v}$ nachalnoy shkole [The world around. Features of studying the subject in primary school] (Izdatelskiy dom Akademii Yestestvoznaniya, Moscow, 2017)

7. N.I. Vasilyeva, Nachalnaya shkola, 5, 63-67 (2020).

8. Ye.V. Grigoriyeva, Metodika prepodavaniya yestestvoznaniya v nachalnoy shkole [Methods of teaching natural science in primary school] (Yurayt, Moscow, 2020)

9. D.Yu. Dobrotin, Nachalnaya shkola, 1, 32-37 (2016)

10. A.A. Pleshakov, Ot zemli do neba: atlas-opredelitel: posobiye dlya uchashchikhsya obshcheobrazovatelnykh uchrezhdeniy [From earth to heaven: an atlas-determinant: a study guide for students of educational institutions] (Prosveshcheniye, Moscow, 2019)

11. Ministry of Education and Science of the Russian Federation, Osnovnaya obrazovatel'naya programma NOO ot 08.04.2015 [The main educational program of primary general education from 08.04.2015] (2015). Accessed on: August 20, 2020. [Online]. Available: https://legalacts.ru/doc/primernaja-osnovnaja-obrazovatelnajaprogramma-nachalnogo-obshchego-obrazovanija-odobrena-resheniem/

12. M.Yu. Oleshkov, V.M. Uvarov, Sovremennyy obrazovatelnyy protsess: osnovnyye ponyatiya i terminy: kratkiy terminologicheskiy slovar [Modern educational process: basic concepts and terms: a short terminological dictionary] (Sputnik+, Moscow, 2006)

13. L.I. Solovyov, Kniga o prirode Kuzbassa: dlya mladshikh shkolnikov i ikh roditeley [A book about the nature of Kuzbass: for younger students and their parents] (Kuzbass, Kemerovo, 2008)

14. T.B. Kropocheva, Rodnoy kray [Homeland], Study guide for primary school students (Polygraphist, Novokuznetsk, 2016)

15. V.F. Natali, Biologicheskiye ekskursii po g. Moskve i blizhayshim okrestnostyam [Biological excursions around Moscow and the immediate vicinity] (Novaya Moskva, Moscow, 1925) 